\title{
Lifestyle Issues and Prevention of Recurrent UTIs
}

\author{
Abdul Kader Mohiuddin* \\ Faculty of Pharmacy, Bangladesh \\ *Corresponding author: Abdul Kader Mohiuddin, Faculty of Pharmacy, WUB, Lake Drive Road Sector: Sector - 7, Uttara, \\ Dhaka, Bangladesh
}

\begin{tabular}{|c|c|}
\hline ARTICLE INFO & ABSTRACT \\
\hline Received: 慧 September 09, 2019 & Citation: Abdul Kader Mohiuddin. Lifestyle Issues and Prevention of Recurrent UTIs. \\
\hline Published: 幽 September 24, 2019 & Biomed J Sci \& Tech Res 21(3)-2019. BJSTR. MS.ID.003618. \\
\hline
\end{tabular}

\section{Mini Review}

UTI is one of the most prevalent diseases with diverse etiological agents annually affecting 250 million and causes death of 150 million people worldwide [1,2]. Adult women are 30 times more likely than men to develop a UTI [3]. Although the estimated mortality rate is generally lower than with RTIs, it may rise up to $26 \%$ if complicated with bacteremia or septic shock [4]. Financial burden of UTIs exceeds $\$ 3.5$ billion in US alone [5] whereas more than $50 \%$ of the antibiotics prescribed for a suspected UTI in older adults being considered unnecessary [6]. More interestingly, nosocomial UTIs account for nearly $40 \%$ of all hospital acquired infections [7] and around 50\% of UTI in children are missed [8]. Recurrent UTIs (RUTIs) are mostly caused by frequent sexual intercourse, heterosexual lack of circumcision receptive anal intercourse (without a condom), multiple sexual partners (each sex partner shares his/her UGT microbiota with the other), use of spermicide and a new sexual partner, sexual intercourse with addicted partners, sexual intercourse with sex workers, sexual intercourse with online dating friends, sexual intercourse with a new sex partner within less than 2 months [9-20]. Traditional lifestyle factors such as fluid intake and diet are not considered independent risk factors now [15]. UTIs account for nearly $25 \%$ of all infections [16].

Sexual intercourse $\geq 3$ times/week was associated with greater frequency of UTI [21]. Close proximity of the urethral meatus to the anus and shorter urethra, is a likely factor [22-26]. Many other factors have been thought to predispose women to RUTIs, such as voiding patterns pre- and post-coitus, wiping technique, wearing tight undergarments, deferred voiding habits and vaginal douching; nevertheless, there has been no proven association [16]. Although, genital hygiene practices such as frequency of coitus, urinating

after coitus, washing genitals precoitus, male partner washing genitals precoitus, washing genitals postcoitus, taking baths, frequent replacing of underwear, and washing genitals from front to back were associated with a reduced frequency of UTIs [21]. Low socioeconomic status, depression, anxiety, inadequate water intake, low educational status, anemia, catheterization, poor personal hygiene, poor access to condoms and other contraceptive devices, spermicide-coated condoms, poor access to qualified healthcare systems, high rate of family disruption, mental disorders are also risk factors [14,27-45]. Catheter-associated-UTIs are common in more than $80 \%$ of all ICU patients with indwelling catheter (more than 1 million such cases found in US) [46,47] and should be avoided unless there is medically necessity [48]. Dietary habits seem to be an important risk factor for UTI recurrence dietary guidance could be a first step toward prevention [42,43], [46-57].

After anemia, UTIs are the second common complications in pregnant women [58]. The overall prevalence of bacteriuria in pregnant women was reported to be as high as $40 \%[2,59$ $66]$ and up to up to $70 \%$ of pregnant women develop glycosuria which encourages bacterial growth in the urine [21]. Preventative measures such as drinking cranberry juice (urinary alkalization), OTC cystitis relief remedies or following certain hygiene behaviors, like wiping the genitals from front to back etc., were some of the measures that was suggested in different studies [5,15,16,21,6774] and also opposed/proven not much effective by other studies $[75,76]$. However, UTI prevention is necessary as renal scarring [77], low birth weight, neonatal UTI, premature labor, preterm birth, hypertension, preeclampsia, septic shock, malformation or stillbirth, anorectal malformation and increased incidence of perinatal death are reported in several studies $[2,21,58,60,61,78$ - 
96]. Circumcision, glycemic control in diabetes, avoiding spicy food, certain dairy products, sweet fizzy drinks, alcohol found helpful in individuals susceptible to UTIs [97-102].

\section{Acknowledgement}

I'm thankful to Dr. Ana L. Flores-Mireles, Department of Molecular Microbiology and Center for Women's Infectious Disease Research, Washington University School of Medicine, Missouri, USA for her precious time to review my literature and thoughtful suggestions. Also, I'm also grateful to seminar library of Faculty of Pharmacy, University of Dhaka and BANSDOC Library, Bangladesh for providing me books, journal and newsletters.

\section{Conflict of Interest}

The author declares that he has no competing interests.

\section{References}

1. Mama M, Manilal A, Gezmu T, Kidanewold A, Gosa F, et al. (2018) Prevalence and associated factors of urinary tract infections among diabetic patients in Arba Minch Hospital, Arba Minch province South Ethiopia. Turkish journal of urology 45(1): 56-62.

2. Azami M, Jaafari Z, Masoumi M, Shohani M, Badfar G, et al. (2019) The etiology and prevalence of urinary tract infection and asymptomatic bacteriuria in pregnant women in Iran: a systematic review and Metaanalysis. BMC urology 19(1): 43.

3. Brush JL (2018) Urinary Tract Infection (UTI) in Males.

4. Shih WY, Chang CC, Tsou MT, Chan HL, Chen YJ, et al. (2019) Incidence and Risk Factors for Urinary Tract Infection in an Elder Home Care Population in Taiwan: A Retrospective Cohort Study. International journal of environmental research and public health 16(4): 566.

5. Liska DJ, Kern HJ, Maki KC (2016) Cranberries and Urinary Tract Infections: How Can the Same Evidence Lead to Conflicting Advice? Advances in nutrition (Bethesda, Md) 7(3): 498-506.

6. Gharbi M, Drysdale JH, Lishman H, Goudie R, Molokhia M, et al. (2019) Antibiotic management of urinary tract infection in elderly patients in primary care and its association with bloodstream infections and allcause mortality: population-based cohort study. BMJ (Clinical research ed) $364: 525$

7. Milovanovic T, Dumic I, Veličkovic J, Lalosevic MS, Nikolic V, et al. (2019) Epidemiology and risk factors for multi-drug resistant hospital-acquired urinary tract infection in patients with liver cirrhosis: single center experience in Serbia. BMC infectious diseases 19(1): 141.

8. Shrestha LB, Baral R, Poudel P, Khanal B (2019) Clinical, etiological and antimicrobial susceptibility profile of pediatric urinary tract infections in a tertiary care hospital of Nepal. BMC pediatrics 19(1): 36.

9. Abdul Kader Mohiuddin (2019) Alternative Management of Uncomplicated UTIs In Women. J Urol Neph St 2(2): 147-151.

10. Vasilenko SA, Rice CE, Rosenberger JG (2018) Patterns of Sexual Behavior and Sexually Transmitted Infections in Young Men Who Have Sex with Men. Sexually transmitted diseases 45(6): 387-393.

11. Owen BN, Elmes J, Silhol R, Dang Q, Mc Gowan I, et al. (2017) How common and frequent is heterosexual anal intercourse among South Africans? A systematic review and meta-analysis. Journal of the International AIDS Society 19(1): 21162.

12. Budkaew J, Chumworathayi B, Pientong C, Ekalaksananan T (2019) Prevalence and factors associated with gonorrhea infection with respect to anatomic distributions among men who have sex with men. PloS one 14(4): e0211682.

13. D'Anna LH, Warner L, Margolis AD, Korosteleva OA, O'Donnell L, et al. (2015) Consistency of Condom Use During Receptive Anal Intercourse
Among Women and Men Who Have Sex With Men: Findings From the Safe in the City Behavioral Study. Sex Transm Dis 42(7): 393-399.

14. Behzadi P, Behzadi E, Pawlak Adamska EA (2019) Urinary tract infections (UTIs) or genital tract infections (GTIs)? It's the diagnostics that count. GMS hygiene and infection control 14: Doc 14.

15. Jhang JF, Kuo HC (2017) Recent advances in recurrent urinary tract infection from pathogenesis and biomarkers to prevention. $\mathrm{Ci}$ ji yi xue za zhi 29(3): 131-137.

16. Al Badr A, Al Shaikh G (2013) Recurrent Urinary Tract Infections Management in Women: A review. Sultan Qaboos University medical journal 13(3): 359-367.

17. Boeri L, Capogrosso P, Ventimiglia E, Scano R, Graziottin A, et al. (2017) Six Out of Ten Women with Recurrent Urinary Tract Infections Complain of Distressful Sexual Dysfunction - A Case-Control Study. Scientific reports 7: 44380 .

18. Storme 0, Tirán Saucedo J, Garcia Mora A, Dehesa Dávila M, Naber KG (2019) Risk factors and predisposing conditions for urinary tract infection. Therapeutic advances in urology 11: 1756287218814382.

19. Maharjan G, Khadka P, Siddhi Shilpakar G, Chapagain G, Dhungana GR (2018) Catheter-Associated Urinary Tract Infection and Obstinate Biofilm Producers. The Canadian journal of infectious diseases \& medical microbiology 7624857

20. Sutcliffe S, Jemielita T, Lai HH, Andriole GL, Bradley CS, et al. (2018) A Case-Crossover Study of Urological Chronic Pelvic Pain Syndrome Flare Triggers in the MAPP Research Network. The Journal of urology 199(5): 1245-1251.

21. Badran YA, El Kashef TA, Abdelaziz AS, Ali MM (2015) Impact of genital hygiene and sexual activity on urinary tract infection during pregnancy. Urology annals 7(4): 478-481.

22. Oladeinde BH, Omoregie R, Olley M, Anunibe JA (2011) Urinary tract infection in a rural community of Nigeria. North American journal of medical sciences 3(2): 75-77.

23. Najar MS, Saldanha CL, Banday KA (2009) Approach to urinary tract infections. Indian journal of nephrology 19(4): 129-139.

24. Hickling DR, Sun TT, Wu XR (2015) Anatomy and Physiology of the Urinary Tract: Relation to Host Defense and Microbial Infection. Microbiology spectrum 3(4).

25. Sumati AH, Saritha NK (2009) Association of urinary tract infection in women with bacterial vaginosis. Journal of global infectious diseases 1(2): 151-152.

26. Minardi D, D’Anzeo G, Cantoro D, Conti A, Muzzonigro G (2011) Urinary tract infections in women: etiology and treatment options. International journal of general medicine 4: 333-343.

27. Pete P, Biguioh RM, Izacar A, Adogaye S, Nguemo C (2019) Genital hygiene behaviors and practices: A cross-sectional descriptive study among antenatal care attendees. Journal of public health in Africa 10(1): 746.

28. August SL, De Rosa MJ (2012) Evaluation of the prevalence of urinary tract infection in rural Panamanian women. PloS one 7(10): e47752.

29. Renard J, Ballarini S, Mascarenhas T, Zahran M, Quimper E, et al. (2014) Recurrent Lower Urinary Tract Infections Have a Detrimental Effect on Patient Quality of Life: a Prospective, Observational Study. Infectious diseases and therapy 4(1): 125-135.

30. Medina M, Castillo Pino E (2019) An introduction to the epidemiology and burden of urinary tract infections. Therapeutic advances in urology 11: 1756287219832172

31. Martin S, Vincent A, Taylor AW, Atlantis E, Jenkins A, et al. (2015) Lower Urinary Tract Symptoms, Depression, Anxiety and Systemic Inflammatory Factors in Men: A Population-Based Cohort Study. PloS one 10(10): e0137903.

32. Sanford MT, Rodriguez LV (2017) The role of environmental stress on lower urinary tract symptoms. Curr Opin Urol 27(3): 268-273. 
33. Emiru T, Beyene G, Tsegaye W, Melaku S (2013) Associated risk factors of urinary tract infection among pregnant women at Felege Hiwot Referral Hospital, Bahir Dar, North West Ethiopia. BMC research notes 6: 292.

34. Kabugo D, Kizito S, Ashok DD, Graham KA, Nabimba R, et al. (2016) Factors associated with community-acquired urinary tract infections among adults attending assessment centre, Mulago Hospital Uganda. African health sciences 16(4): 1131-1142.

35. Tewary K, Narchi H (2015) Recurrent urinary tract infections in children: Preventive interventions other than prophylactic antibiotics. World journal of methodology 5(2): 13-19.

36. Derese B, Kedir H, Teklemariam Z, Weldegebreal F, Balakrishnan S (2016) Bacterial profile of urinary tract infection and antimicrobial susceptibility pattern among pregnant women attending at Antenatal Clinic in Dil Chora Referral Hospital, Dire Dawa, Eastern Ethiopia. Therapeutics and clinical risk management 12: 251-260.

37. Fihn SD, Boyko EJ, Chen CL, Normand EH, Yarbro P, et al. (1998) Use of spermicide-coated condoms and other risk factors for urinary tract infection caused by Staphylococcus saprophyticus. Arch Intern Med 158(3): 281-287

38. Dienye PO, Gbeneol PK (2011) Contraception as a risk factor for urinary tract infection in Port Harcourt, Nigeria: A case control study. African Journal of Primary Health Care \& Family Medicine 3(1): 207.

39. Sen A (2008) Recurrent cystitis in non-pregnant women. BMJ clinical evidence p. 0801

40. Schmiemann G, Kniehl E, Gebhardt K, Matejczyk MM, Hummers Pradier E (2010) The diagnosis of urinary tract infection: a systematic review. Deutsches Arzteblatt international 107(21): 361-367.

41. Scholes D, Hooton TM, Roberts PL, Gupta K, Stapleton AE, et al. (2005) Risk factors associated with acute pyelonephritis in healthy women. Annals of internal medicine 142(1): 20-27.

42. Vyas S, Sharma P, Srivastava K, Nautiyal V, Shrotriya VP (2015) Role of Behavioural Risk Factors in Symptoms Related to UTI Among Nursing Students. Journal of clinical and diagnostic research 9(9): LC15-LC18.

43. Mishra B, Srivastava R, Agarwal J, Srivastava S, Pandey A (2016) Behavioral and Psychosocial Risk Factors Associated with First and Recurrent Cystitis in Indian Women: A Case-control Study. Indian journal of community medicine 41(1): 27-33.

44. Das P, Baker KK, Dutta A, Swain T, Sahoo S, et al. (2015) Menstrual Hygiene Practices, WASH Access and the Risk of Urogenital Infection in Women from Odisha, India. PloS one 10(6): e0130777.

45. Haque M, Sartelli M, Mc Kimm J, Abu Bakar M (2018) Health careassociated infections - an overview. Infection and drug resistance 11 2321-2333.

46. Assadi F (2018) Strategies for Preventing Catheter-associated Urinary Tract Infections. International journal of preventive medicine 9(1): 50 .

47. Karishetti MS, Shaik HB (2019) Clinicomicrobial assessment of urinary tract infections in a tertiary care hospital. Indian J Health Sci Biomed Res 12(1): 69-74

48. Saint S, Greene MT, Krein SL, Rogers MA, Ratz D, et al. (2016) A Program to Prevent Catheter-Associated Urinary Tract Infection in Acute Care. N Engl J Med 374(22): 2111-2119.

49. Tero Kontiokari, Jaana Laitinen, Leea Järvi, Tytti Pokka, Kaj Sundqvist, et al. (2003) Dietary factors protecting women from urinary tract infection. The American Journal of Clinical Nutrition 77(3): 600-604.

50. Foxman B, Frerichs RR (1985) Epidemiology of urinary tract infection: II Diet, clothing, and urination habits. American journal of public health 75(11): 1314-1317.

51. Nordstrom L, Liu CM, Price LB (2013) Foodborne urinary tract infections: a new paradigm for antimicrobial-resistant foodborne illness. Frontiers in microbiology 4: 29.

52. Manges AR, Smith SP, Lau BJ, Nuval CJ, Eisenberg JN, et al. (2007) Retail meat consumption and the acquisition of antimicrobial resistant
Escherichia coli causing urinary tract infections: a case-control study. Foodborne Pathog Dis 4(4): 419-31.

53. Kontiokari T, Laitinen J, Järvi L, Pokka T, Sundqvist K, et al. (2003) Dietary factors protecting women from urinary tract infection. Am J Clin Nutr 77(3): 600-604.

54.Singer RS (2015) Urinary tract infections attributed to diverse ExPEC strains in food animals: evidence and data gaps. Frontiers in microbiology 6: 28.

55. Søraas A, Sundsfjord A, Sandven I, Brunborg C, Jenum PA (2013) Risk factors for community-acquired urinary tract infections caused by ESBLproducing enterobacteriaceae--a case-control study in a low prevalence country. PloS one 8(7): e69581.

56. Kalas V, Hibbing ME, Maddirala AR, Chugani R, Pinkner JS, et al. (2018) Structure-based discovery of glycomimetic FmlH ligands as inhibitors of bacterial adhesion during urinary tract infection. Proc Natl Acad Sci U S A 115(12): E2819-E2828.

57. Gessese YA, Damessa DL, Amare MM, Bahta YH, Shifera AD, et al. (2017) Urinary pathogenic bacterial profile, antibiogram of isolates and associated risk factors among pregnant women in Ambo town, Central Ethiopia: a cross-sectional study. Antimicrobial resistance and infection control 6: 132.

58. Amiri M, Lavasani Z, Norouzirad R, Najibpour R, Mohamadpour M, et al. (2015) Prevalence of Urinary Tract Infection Among Pregnant Women and its Complications in Their Newborns During the Birth in the Hospitals of Dezful City, Iran, 2012 - 2013. Iranian Red Crescent medical journal 17(8): e26946.

59. Szweda H, Jóźwik M (2016) Urinary tract infections during pregnancy an updated overview. Dev Period Med 20(4): 263-272.

60. Matuszkiewicz Rowińska J, Małyszko J, Wieliczko M (2015) Urinary tract infections in pregnancy: old and new unresolved diagnostic and therapeutic problems. Archives of medical science: AMS 11(1): 67-77.

61. Kalinderi K, Delkos D, Kalinderis M, Athanasiadis A, Kalogiannidis I (2018) Urinary tract infection during pregnancy: current concepts on a common multifaceted problem. J Obstet Gynaecol 38(4): 448-453.

62. Yan L, Jin Y, Hang H, Yan B (2018) The association between urinary tract infection during pregnancy and preeclampsia: A meta-analysis. Medicine 97(36): e12192.

63. Ghouri F, Hollywood A, Ryan K (2018) A systematic review of nonantibiotic measures for the prevention of urinary tract infections in pregnancy. BMC pregnancy and childbirth 18(1): 99.

64. Ailes EC, Summers AD, Tran EL, Gilboa SM, Arnold KE, et al. (2018) Antibiotics Dispensed to Privately Insured Pregnant Women with Urinary Tract Infections - United States 2014. MMWR Morbidity and mortality weekly report 67(1): 18-22.

65. Hamdan HZ, Ziad AH, Ali SK, Adam I (2011) Epidemiology of urinary tract infections and antibiotics sensitivity among pregnant women at Khartoum North Hospital. Annals of clinical microbiology and antimicrobials 10: 2 .

66. Angelescu K, Nussbaumer Streit B, Sieben W, Scheibler F, Gartlehner G (2016) Benefits and harms of screening for and treatment of asymptomatic bacteriuria in pregnancy: a systematic review. BMC pregnancy and childbirth 16(1): 336

67. Ghouri F, Hollywood A, Ryan K (2019) Urinary tract infections and antibiotic use in pregnancy - qualitative analysis of online forum content. BMC pregnancy and childbirth 19(1): 289.

68. Jepson RG, Williams G, Craig JC (2012) Cranberries for preventing urinary tract infections. Cochrane Database Syst Rev 10: CD001321.

69. Heitmann K, Nordeng H, Holst L (2013) Pregnancy outcome after use of cranberry in pregnancy--the Norwegian Mother and Child Cohort Study. BMC complementary and alternative medicine 13: 345.

70. Allan GM, Nicolle L (2013) Cranberry for preventing urinary tract infection. Canadian family physician Medecin de famille canadien 59(4): 367. 
71. Hisano M, Bruschini H, Nicodemo AC, Srougi M (2012) Cranberries and lower urinary tract infection prevention. Clinics (Sao Paulo, Brazil) 67(6): 661-668.

72. Asma B, Vicky L, Stephanie D, Yves D, Amy H, et al. (2018) Standardised high dose versus low dose cranberry Proanthocyanidin extracts for the prevention of recurrent urinary tract infection in healthy women [PACCANN]: a double blind randomised controlled trial protocol. BMC urology 18(1): 29.

73. Beerepoot M, Geerlings S (2016) Non-Antibiotic Prophylaxis for Urinary Tract Infections. Pathogens (Basel, Switzerland) 5(2): 36.

74. Hickling DR, Nitti VW (2013) Management of recurrent urinary tract infections in healthy adult women. Reviews in urology 15(2): 41-48.

75. Abbo LM, Hooton TM (2014) Antimicrobial Stewardship and Urinary Tract Infections. Antibiotics (Basel, Switzerland) 3(2): 174-192.

76. Barbosa Cesnik C, Brown MB, Buxton M, Zhang L, De Busscher J, et al. (2011) Cranberry juice fails to prevent recurrent urinary tract infection: results from a randomized placebo-controlled trial. Clinical infectious diseases 52(1): 23-30.

77. Wang HH, Kurtz M, Logvinenko T, Nelson C (2019) Why Does Prevention of Recurrent Urinary Tract Infection not Result in Less Renal Scarring? A Deeper Dive into the RIVUR Trial. J Urol 202(2): 400-405.

78. Wingert A, Pillay J, Sebastianski M, Gates M, Featherstone R, et al (2019) Asymptomatic bacteriuria in pregnancy: systematic reviews of screening and treatment effectiveness and patient preferences. BMJ open 9(3): e021347.

79. Khalesi N, Khosravi N, Jalali A, Amini L (2014) Evaluation of maternal urinary tract infection as a potential risk factor for neonatal urinary tract infection. Journal of family \& reproductive health 8(2): 59-62.

80. Eliakim A, Dolfin T, Korzets Z, Wolach B, Pomeranz A (1997) Urinary tract infection in premature infants: the role of imaging studies and prophylactic therapy. J Perinatol 17(4): 305-308.

81. Gilbert NM, O'Brien VP, Hultgren S, Macones G, Lewis WG, et al. (2013) Urinary tract infection as a preventable cause of pregnancy complications: opportunities, challenges, and a global call to action. Global advances in health and medicine 2(5): 59-69.

82. Kaul AK, Khan S, Martens MG, Crosson JT, Lupo VR, et al. (1999) Experimental gestational pyelonephritis induces preterm births and low birth weights in $\mathrm{C} 3 \mathrm{H} / \mathrm{HeJ}$ mice. Infection and immunity 67(11): 59585966.

83. Jain V, Das V, Agarwal A, Pandey A (2013) Asymptomatic bacteriuria \& obstetric outcome following treatment in early versus late pregnancy in north Indian women. The Indian journal of medical research 137(4): 753-758.

84. Dimetry SR, El Tokhy HM, Abdo NM, Ebrahim MA, Eissa M (2007) Urinary tract infection and adverse outcome of pregnancy. J Egypt Public Health Assoc 82(3-4): 203-218.

85. Mohseny AB, Van Velze V, Steggerda SJ, Smits Wintjens V, Bekker V, et al. (2018) Late-onset sepsis due to urinary tract infection in very preterm neonates is not uncommon. European journal of pediatrics 177(1): 3338.

86. Leviton A, Allred EN, Kuban KC, O’ Shea TM, Paneth N, et al. (2016) The Development of Extremely Preterm Infants Born to Women Who Had Genitourinary Infections During Pregnancy. American journal of epidemiology 183(1): 28-35.
87. Bauer S, Eliakim A, Pomeranz A, Regev R, Litmanovits I, et al. (2003) Urinary tract infection in very low birth weight preterm infants. Pediatr Infect Dis J 22(5): 426-430.

88. Verma I, Avasthi K, Berry V (2014) Urogenital infections as a risk factor for preterm labor: a hospital-based case-control study. Journal of obstetrics and gynaecology of India 64(4): 274-278.

89. Hosny AEMS, El Khayat W, Kashef MT, Fakhry MN (2017) Association between preterm labor and genitourinary tract infections caused by Trichomonas vaginalis, Mycoplasma hominis, Gram-negative bacilli, and coryneforms. J Chin Med Assoc 80(9): 575-581.

90. Kaduma J, Seni J, Chuma C, Kirita R, Mujuni F, et al. (2019) Urinary Tract Infections and Preeclampsia among Pregnant Women Attending Two Hospitals in Mwanza City, Tanzania: A 1:2 Matched Case-Control Study. Bio Med research international.

91. Easter SR, Cantonwine DE, Zera CA, Lim KH, Parry SI, et al. (2016) Urinary tract infection during pregnancy, angiogenic factor profiles, and risk of preeclampsia. Am J Obstet Gynecol 214(3): 387e1-387e7.

92. Karmon A, Sheiner E (2008) The relationship between urinary tract infection during pregnancy and preeclampsia: causal, confounded or spurious? Arch Gynecol Obstet 277(6): 479-481.

93. Edefonti A, Tel F, Testa S, De Palma D (2014) Febrile urinary tract infections: clinical and laboratory diagnosis, imaging, and prognosis. Semin Nucl Med 44(2): 123-128.

94. Vachvanichsanong P (2007) Urinary tract infection: one lingering effect of childhood kidney diseases--review of the literature. J Nephrol 20(1): 21-28.

95. Bánhidy F, Acs N, Puhó EH, Czeizel AE (2006) Maternal urinary tract infection and related drug treatments during pregnancy and risk of congenital abnormalities in the offspring. BJOG 113(12): 1465-1471.

96. Sanchez S, Ricca R, Joyner B, Waldhausen JH (2014) Vesicoureteral reflux and febrile urinary tract infections in anorectal malformations: a retrospective review. J Pediatr Surg 49(1): 91-94.

97. Eisenberg ML, Galusha D, Kennedy WA, Cullen MR (2018) The Relationship between Neonatal Circumcision, Urinary Tract Infection, and Health. The world journal of men's health 36(3): 176-182.

98. Odoki M, Almustapha Aliero A, Tibyangye J, Nyabayo Maniga J, Wampande E, et al. (2019) Prevalence of Bacterial Urinary Tract Infections and Associated Factors among Patients Attending Hospitals in Bushenyi District, Uganda. International journal of microbiology.

99. Nitzan O, Elias M, Chazan B, Saliba W (2015) Urinary tract infections in patients with type 2 diabetes mellitus: review of prevalence, diagnosis, and management. Diabetes, metabolic syndrome and obesity 8: 129136.

100. Bharti A, Chawla S, Kumar S, Kaur S, Soin D, et al. (2019) Asymptomatic bacteriuria among the patients of type 2 diabetes mellitus. Journal of family medicine and primary care 8(2): 539-543.

101. Flower A, Bishop FL, Lewith G (2014) How women manage recurrent urinary tract infections: an analysis of postings on a popular web forum. BMC family practice 15: 162 .

102. Oaklander M (2015) Your Diet May Be Causing Your Urinary Tract Infections Time. Magazine. 


\section{ISSN: 2574-1241}

DOI: $10.26717 /$ BJSTR.2019.21.003618

Abdul Kader Mohiuddin. Biomed J Sci \& Tech Res

(C) This work is licensed under Creative

Submission Link: https://biomedres.us/submit-manuscript.php

$\begin{array}{ll}\text { BIOMEDICAL } & \text { Assets of Publishing with us } \\ \text { RESEARCHES } & \text { - Global archiving of articles } \\ & \text { - Immediate, unrestricted online access } \\ & \text { - Rigorous Peer Review Process } \\ \end{array}$

